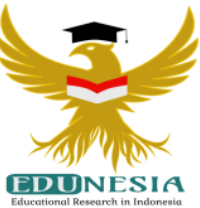

\title{
Communication in the Industrial Revolution Era 4.0 Through Learning Based Learning and Inquiry
}

\author{
Denny Denmar'; Bradley Setiyadi2; Sophia Rahmawati ${ }^{3}$ \\ 1,2,3Education Administration, FKIP Universitas Jambi, Indonesia \\ 2Corresponding Email: bradleysetiyadi@unja.ac.id, Phone Number : 0812 xxxx xxxx
}

\author{
Article History: \\ Received: Feb 18, 2021 \\ Revised: Apr 10, 2021 \\ Accepted: Apr 13, 2021 \\ Online First: May 02, 2021
}

\section{Keywords:}

Communication

Industrial Revolution 4.0, Inquiry, Problem Based Learning.

\section{Kata Kunci:}

Inkuiri, Komunikasi, Problem Based Learning, Revolusi Industri 4.0.

\section{How to cite:}

Denmar, D., Setiyadi, B., \& Rahmawati, S. (2021). Communication in the Industrial Revolution Era 4.0 Through Learning Based Learning and Inquiry. Edunesia: Jurnal Ilmiah Pendidikan, 2 (2): 481-489.

This is an open access article under the $C C-B Y-N C-N D$ license (c) $(\$) \ominus$

\begin{abstract}
Communication is known as an activity carried out verbally and nonverbally. Communication involves a large number of XXI century skills such as analysis, evaluation, problem solving, metacognition, collaboration, and technology. Some content standards that were built as a foundation for CCSS (Common Core State Standards) target communication skills in the ability to write, speak, and listen. Communication skills of jambi university education administration students seem to be lacking. This is reinforced by the results of observations, when discussion groups of students find it difficult to convey ideas verbally and difficulty in writing ideas into summaries. Lack of communication skills is influenced by many factors. While communication skills are very important possessed by students especially in the industrial era 4.0. One solution to improve communication skills is to integrate learning models. learning models that can be integrated are problem based learning and inquiry. The purpose of this study was to determine the improvement of communication skills of jambi university education administration students through the problem based learning model and the inquiry model. This research is a classroom action research (CAR) conducted in cycles of 4 stages, namely: planning, implementing, observing, and reflecting. The results of this CAR indicate that the inquiry model has not been able to show any indication of changes in improving communication skills of Educational Administration students in Jambi University.
\end{abstract}

Abstrak: Komunikasi dikenal sebagai kegiatan yang dilakukan secara verbal dan non- verbal. Komunikasi melibatkan sejumlah besar keterampilan abad XXI seperti analisis, evaluasi, pemecahan masalah, metakognisi, kolaborasi, dan teknologi. Beberapa standar isi yang dibangun sebagai landasan CCSS (Common Core State Standards) menargetkan kemampuan komunikasi pada kemampuan menulis, berbicara, dan mendengarkan. Kemampuan komunikasi mahasiswa Admistrasi Pendidikan Universitas Jambi terlihat kurang. Hal ini diperkuat dengan hasil observasi, pada saat diskusi kelompok mahasiswa kesulitan untuk menyampaikan gagasan secara verbal dan kesulitan untuk menuliskan gagasan kedalam ringkasan. Kurangnya kemampuan komunikasi dipengaruhi oleh banyak faktor. Sedangkan kemampuan komunikasi sangat penting dimiliki oleh mahasiswa terlebih lagi di era industri 4.0. Salah satu solusi untuk meningkatkan kemampuan komunikasi adalah mengintegrasikan model pembelajaran. model pembelajaran yang dapat diintegrasikan adalah problem based learning dan inkuiri. Tujuan penelitian ini adalah untuk mengetahui peningkatan kemampuan komunikasi mahasiswa administrasi pendidikan universitas jambi melalui model problem based learning dan model inkuiri. Penelitian ini merupakan penelitian tindakan kelas (PTK) yang dilakukan secara bersiklus dengan 4 tahapan, yaitu: perencanaan, pelaksanaan, observasi, dan refleksi. Hasil PTK ini menunjukkan bahwa model inquiri belum dapat menunjukkan adanya indikasi perubahan dalam dapat meningkatkan kemampuan komunikasi mahasiswa Administrasi Pendidikan Universitas Jambi. 


\section{A. Introduction}

Communication is an important part of everyday life. Forms of communication can be written and oral. In learning, communication is needed by students as a way of expressing opinions and obtaining knowledge. Student communication skills need to be developed by providing open problems (Sumartini, 2019). Students must have good communication skills, especially in the era of the 4.0 revolution so that when they have entered the real world students do not stutter for communication. Some of the content standards that were built as the foundation of the CCSS (Common Core State Standards) target communication skills in writing, speaking, and listening skills (Prasetyo \& Trisyanti, 2018). The students' communication skills in writing, speaking, and listening will be improved.

The industrial revolution 4.0 is the development of the fourth industrial revolution (Tjandrawinata, et al., 2016), namely: “The first Industrial Revolution (IR), which began in 1784 , enriched water and steam power for mechanization of the production system. The second IR, which began in 1870, used electric power to carry out mass production. Meanwhile, the third IR, which began in 1969, used the power of electronics and information technology to automate the production process. In this century, IR has entered its fourth era, namely the world has obtained the internet with fast interconnectivity, by being able to explore the virtual world using computers".

The term industrial revolution was introduced by Friedrich Engels and LouisAugusteBlanqui in the middle of the 19th century. The industrial revolution has been going on from time to time. The last decade has been said to have entered the fourth phase of 4.0. change from phase to phase gives a difference in each period in terms of its usefulness. The first phase (1.0) takes the discovery of a machine that focuses (stressing) on the mechanization of production. The second phase (2.0) has moved to a mass production stage that is integrated with quality control and standardization. The third phase (3.0) enters the mass uniformity stage which relies on computerized integration. The fourth phase (4.0) has presented the digitization and automation of the internet fusion by manufacturing industrial engineering higher education organizing cooperation agency (Suwardana, 2017).

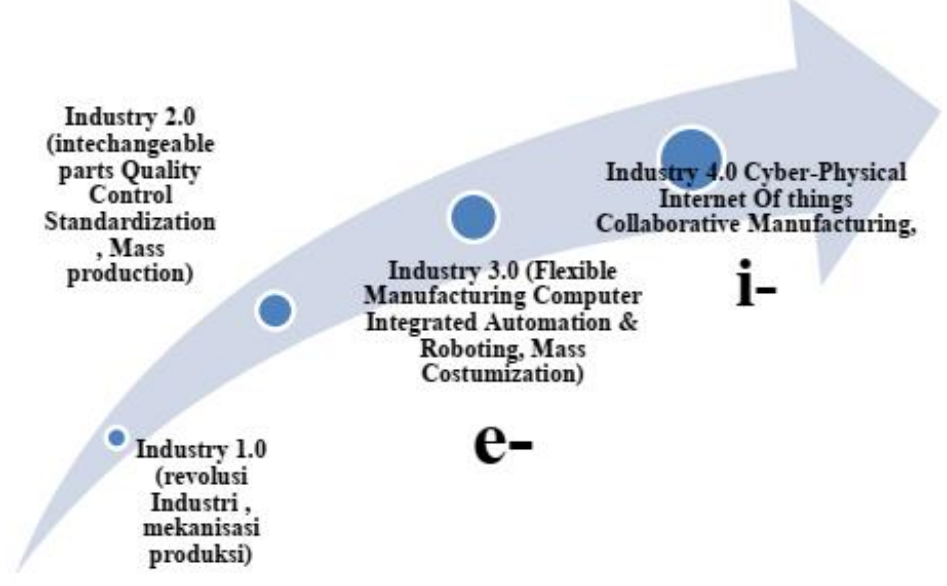

Figure 1. Phase of industrial revolution

Communication is known as an activity that is carried out verbally and non-verbally. However, the definition that we understand about communication based on the rapid 
development of information today involves interactions that take place in different areas, this shifts the traditional communication paradigm which requires direct meetings. The areas in question include face to face interactions involving information technology (IT), digital literacy, email, short messages, social media and virtual environments (Deakin Teaching Team, 2013). Communication involves a large number of XXI century skills such as analysis, evaluation, problem solving, metacognition, collaboration and technology. Some of the content standards built as the foundation for the CCSS target communication skills in writing, speaking and listening skills as follows: 1) writing informative texts to test and convey complex ideas and information. 2) producing clear and sustainable in developing context, organization, and appropriate writing style for tasks, goals and audiences. 3) presenting information and findings that can be understood by listeners with appropriate methods. 4) adapting speaking styles to various contexts and communicative tasks, 5) actively participating in conversations involving different colleagues or partners, 6) integrating and evaluating information presented in different media formats (Greenstein, L. 2012). Communication skills can be further integrated into various subject matter at all levels of education which includes reading, listening and observing activities.The process of transferring information and solving problems conveyed through language are the main abilities (Greenstein, 2012). The things that need to be understood in communicating specifically can be adjusted according to their types, namely oral communication, written communication and interpersonal communication which are detailed as follows: 1) oral communication, oral communication can be in the form of presentations, discussions, debates, interviews, meetings and so on. This type of communication can be the task most students face. The pressure when going to do a presentation can be unavoidable. Here are some things that should be considered when communicating orally: empathy, Using visual effects in a presentation, Amount of information/detailed visual aided information handout supplies, audience feedback, responding to audience questions, Voice modulation (intonation), voice volume (pitch), eye contact, the speaker's position when speaking in a room. 2). written communication, written communication is very diverse. This can be in the form of writing applications, proposals, promotions, letters, memos, emails, publications, reports, press releases, and so on. 3) Interpersonal communication, interpersonal communication or communication between individuals, contains several aspects that need to be considered, namely: emotional intelligence, body language and posture, sensitivity to the audience demonstrated through proper behavior and active listening (Deakin Teaching Team , 2013).

According to (Huda, 2014) states that the problem based learning (PBL) model is a learning model that prepares students to understand a problem that students must solve in groups. The PBL learning model presents problems related to the environment around students such as the environment around the school, home and the environment where they are located. The problems presented are problems given about natural occurrences that are happening, problems related to student social so that students are able to get used to solving the problems they face in the learning process.

According to (Putra, 2013) states that the problem based learning (PBL) model is preparing students to think critically. Students are able to think critically in facing problems because students are required to face problems that will be solved and to know important concepts from solving problems faced by students. Critical thinking is the ability of students to think scientifically because the PBL model is about solving problems related to everyday 
life but scientifically solving it and it will form students' critical thinking skills in solving a problem.

According to Anam (2016) in language, inquiry comes from the word inquiry which is an investigation or asking for information or in the concept of students being asked to find and find their own. According to Fathurrohman (2015) "inquiry is the art and science of asking and answering questions that require observation and measurement, hypothesis testing and interpretation, reflection, and evaluation". According to Shoimin (2014) explains that the inquiry model is a series of learning activities that emphasize the activeness of students to have learning experiences in finding material concepts based on the problems posed. Furthermore, Trianto (2017) explains that inquiry is a series of learning activities that maximally involves all students' abilities to search and investigate systematically, critically, logically and analytically so that they can formulate answers confidently.

Based on the theories described, it can be concluded that the problem based learning (PBL) learning model is a learning model that prepares students to solve problems scientifically, think critically and actively face problems. Students are prepared to be able to solve problems scientifically, namely using scientific steps to solve problems, can be conveyed by students with the theories they learn, problem-based learning models are able to prepare students to think critically, namely knowing student knowledge in solving problems well. The problem based learning model prepares students to play an active role because students find their own answers to the problems they face.

This study aims, namely: "to determine the effectiveness of the problem based learning model and inquiry model in improving communication skills in the era of the industrial revolution 4.0 in Jambi University Educational Administration students". This classroom action research is expected to be used as study material and comparative study for other researchers related to problems in improving communication skills in the problembased learning model and inquiry model in the era of the industrial revolution 4.0 in Jambi University Educational Administration students.

For students, the results of this study are expected to add insight and knowledge so that students have good communication skills after the application of the problem based learning model and inquiry model. Meanwhile, for lecturers, the results of this study are expected to be input in applying the problem based learning model and inquiry model to be able to improve the communication skills of Educational Administration students.

\section{B. Method}

The subjects of this study were students of the University of Jambi Educational Administration. This research consists of several stages, namely, the preparation stage, the implementation stage, and the stage of data processing and report preparation.

The data collected is in the form of communication skills measured using a written essay test, and communication observation sheets taken from CCSS targeting communication skills on writing, speaking, and listening skills.

Sources of data obtained include observation of activities during the learning process, test scores of communication skills as seen from student essay questions in each cycle, interviews of student communication skills and documentation of activities during the research process.

Data collection techniques are using non-test and test techniques. The non-test technique is in the form of observation, interview, and documentation, while the test technique is in the form of a written test in the form of an essay. The data analysis conducted 
in this research is descriptive analysis. The data obtained from the research results were processed and analyzed qualitatively and quantitatively.

The steps of the problem based learning (PBL) model have 5 stages, namely stage 1 orienting students to the problem, stage 2 organizing students to work, stage 3 guiding individual and group investigations, stage 4 developing and evaluating the problem solving process. While the inquiry learning model has the following stages:

a) Ask a question or problem. Inquiry learning model activities begin when a question or problem is asked, then students are asked to formulate a hypothesis.

b) Formulate a hypothesis. Hypotheses are temporary answers to questions or solutions to problems that can be tested with data. To facilitate this process, the lecturer guides students to determine hypotheses that are relevant to the given problem

c) Collecting data. Hypotheses are used to guide the data collection process. The lecturer guides students to be able to determine data collection steps. The resulting data can be in the form of a table or graph

d) Data analysis. Students are responsible for testing the hypotheses that have been formulated by analyzing the data that has been obtained. After obtaining conclusions, from the experimental data, students can test the hypotheses that have been formulated. If it turns out that the hypothesis is wrong or rejected, students can explain it according to the inquiry learning process they have done.

Make conclusions. The closing step of inquiry learning is to make conclusions based on the data obtained by students.

\section{Result and Discussion}

Research in cycle I is divided into four activities, namely: 1) planning, 2) giving action, 3) observation and 4) reflection. In the first cycle and the first meeting, the researcher started a Classroom Action Research (CAR) to see how the lecturers used the inquiry model to improve the communication skills of students of the Jambi University FKIP Educational Administration Study Program. The indicator to be achieved at the first meeting is understanding the concept. The initial activity of the lecturer was to open the lecture by saying greetings then asking how were they and the students who did not enter. The lecturer delivered the material to be studied at the 1st meeting regarding the basic concepts of communication and conveyed the learning objectives, namely that students could understand the basic concepts of communication.

The core activity of the lecturer is explaining the material on this day, explaining the steps of inquiry learning. Then the lecturer divides the students into groups, each group consisting of 5 to 6 students. After the groups are formed, the lecturer assigns each group to work together to finish according to the material in the group. The assignment given is initial training for students assisted by peers observing student attitudes and seeing the discussion process in each group. Group discussion activities are given 45 minutes, each student is encouraged to be active during the discussion by conveying ideas. Lecturers also help students who have difficulty making assignments and during the discussion process. The lecturer goes around to observe the discussions of each group and guide them. To check their understanding of the assignment given, the lecturer invited students to present the assignment from the results of the discussion and cooperation. At the first meeting of the first cycle, a group came forward to present the results of their discussion. While other groups pay attention and are represented by one person to come forward. 
Among the assigned groups there was 1 group that could not complete the task well. The closing activity of the lecturer provides feedback on questions given to students regarding the material being studied. The lecturer asks students for advanced training at home. The lecturer closes the lesson with greetings. The results from the first cycle of the first meeting, the group did not fully understand the Inquiry learning model and the steps, so that when giving assignments by the lecturer, each group as a whole had difficulty completing the assignments given to the group. The results of observations from the beginning of the discussion to the presentation of the students to the front of the class showed that there was a group that successfully completed the assignment, namely group I, group III, group IV, and group V. While one group that was successfully completed according to the steps in the Inquiry learning model was group I.

Based on the results of observations in cycle I at the first meeting, the results of joint observations with peers are a lot of improvements that must be made at the next meeting, among others: Students do not properly understand the Inquiry learning model; Limited internet access, due to poor signal; Class literacy activities need to be carried out first, before learning begins; and it is necessary to display images in group discussions. Therefore it is necessary to have real action in the next cycle, so that learning can take place well.

At this meeting the lecturer opened the lesson and asked students who were not present today, then the lecturer repeated the previous material so that students could remember the lesson last week. After that, students are directed to pay attention to the competencies and indicators to be achieved. After the second meeting learning process ends and the material will be studied by students at the second meeting and explains the steps of the group discussion that will be carried out by each group, where each group is asked to work together in groups to solve problems according to the material that has been given. Before starting the lesson, the seating position was changed according to the group, this was attempted in every meeting. Then the students sat in their respective groups after that were given the opportunity for 10 minutes for literacy activities, after understanding their respective material, then continued with displaying an infocus in the form of a picture that must be observed by the student so as to give birth to questions. On this occasion, the students' enthusiasm was seen more enthusiastically in answering the pictures on the question.

Group discussion activities run smoothly and orderly, the implementation is assisted by colleagues who carry out the assessment in the group discussion. This activity lasted for approximately 45 minutes, after which some groups were able to complete their assignments faster than the predetermined time, but some groups did not succeed in completing their group assignments on time. The next group assignment is to do the assignment from the lecturer for about 30 minutes, in this case the students are given the task to search for articles on the internet regarding basic concepts of communication. Students look for these assignments through laptops that are connected to the internet in front of the class, the limitations of looking for articles due to short time are tricked by dividing several task groups with campus internet facilities and student cellphones that are connected to the internet provided by the lecturer in front of the class. The implementation of this task seems to be going well in accordance with what was expected, although there are still many students who sit and stand watching their friends search for articles on the internet. After finishing students collect assignments obtained via the internet, then the lecturer closes the lesson. At this meeting, the lecturer emphasized the importance of competencies to be achieved by students at the end of the lesson in accordance with the 
learning objectives stated in the learning plan that had been prepared by the lecturer with the same steps as the previous meeting. Students are emphasized to be able to master these competencies maximally so that learning objectives can be achieved.

Then the researcher formed a group and invited the group to have a discussion with the material that had been given by the lecturer. Before the discussion took place, as usual, the lecturer gave literacy time to students for 15 minutes so that they could understand the learning first. Based on observations during the learning process at this meeting, it appears that there have been changes and student activeness in group discussions. Students no longer feel too confused and remain silent in completing group assignments that have been given by the lecturer. Furthermore, the lecturer is assisted by colleagues to observe the discussion and record everything that happens in the discussion. Then the lecturer conducted an interview with one of the students who was deemed at the first and second meetings not very respectful of his friends in the discussion.

In the interview, the lecturer asked whether there was no participation in helping his friends in group discussions or a lot of silence when his friends were discussing the student was not too focused on his friends in the discussion.discussing, playing alone and paying more attention to his friendsin discussion. The student answered questions from the lecturer that did not understand. Then the lecturer guides the students and provides input so that they can be the same as their other friends. At this meeting activeness had begun to increase as expected by researchers, but the problem of applying the inquiry model in learning was not very successful.

To help improve learning, the lecturer instructs the group to open the internet from students' cellphones to find information and complete assignments according to the steps in learning. Besides that, the lecturer also added other textbook references from the library so that students could easily do their group assignments. The closing activity of the lecturer provides feedback on questions given to students regarding the material being studied. The lecturer asks students for advanced training at home.

Ending the lesson, the lecturer assigns homework to students in the form of paper assignments relating to the basic concepts of communication from several experts and then students are asked to make conclusions, which will be collected at the next meeting. The lecturer closes the lecture with greetings. The obstacles faced by students include the lack of facilities for student study books, then the internet which is not supported because the network is often disrupted or limited.

The results of observing a description of student behavior during the learning process that have been observed by peers as observers in this study, then the lecturer tries to provide a stimulus to stimulate questions that show communicative results. Students try to answer assigned assignments individually. Based on the results of the cycle I test which was carried out on August 26, 2019, the overall results were obtained, that there was an increase in the average test results obtained by students on the exam. Meanwhile, in the pretest, although it has not reached the average completeness, it is considered that there is a change. Broadly speaking, it shows that the Inquiry learning model has succeeded in improving student learning outcomes even though there are still some students whose scores are unstable because the test scores actually decrease but do not really affect them. In accordance with the standards determined from the results of the test cycle I above, it turns out that none of the students passed the predetermined criteria. It is expected that later in cycle II there will be an increase in value and better learning improvements from cycle I. 
Based on the data and student learning outcomes in cycle I, it can be concluded that the increase in student learning outcomes using the inquiry model has not been fully successful or the success indicators that have been determined in the study have not been fulfilled. The failure can be seen from the low student learning outcomes in the implementation of learning. This is due to the constraints the researchers face in the learning process. The constraints faced by researchers in implementing learning activities in cycle I based on the results of researchers and peers are:

1) Many students do not pay attention when the lecturer explains the learning objectives that must be achieved.

2) Many students chat when the lecturer explains the subject matter.

3) Many students do not understand the steps in the discussion.

4) Many students make noise when discussing groups.

5) Only one or two people working in the other groups just watching and chatting.

6) Only how many students ask questions if they do not understand the assignments in group discussions when they do not understand.

7) The attitude of students that they cannot work together in groups if members are not close friends.

8) Students are less active in responding to the results of other groups even though they only ask questions from group representatives

To overcome these obstacles, discussions were held with peers to improve the low learning outcomes in cycle I, from the results of the analysis above it is necessary to carry out cycle 2 , by making several improvements, namely as follows:

1) Maintaining good activity steps in cycle I such as making students who are not noisy in cycle 1 but also in the next cycle.

2) Lecturers must be clearer and more assertive and must be more detailed in conveying learning objectives with the help of power points.

3) Make students more active as a whole and reduce unnecessary things in the discussion such as joking.

4) Make students more focused and enjoy more interesting and fun discussions.

In accordance with the suggestions of students in cycle I at the interview session, that lecturers should give more lecture assignments and homework.

\section{Conclusion}

Based on the findings in classroom action research that has been implemented by applying the problem-based learning model, it was found that the problem-based learning model has not been able to show any indication of changes in improving the communication skills of Jambi University Educational Administration students. This is because classroom action research is still in the first cycle where it is still in the implementation stage/not yet finished.

The results of other temporary findings in classroom action research that has been carried out by applying the inquiry model, it is found that the inquiry model has not been able to show any indication of changes in being able to improve the communication skills of Jambi University Educational Administration students. This is because classroom action research is still in the first cycle which is still in the implementation stage/has not yet been completed. 


\section{Acknowledgment}

Our gratitude goes to the Research and Community Service Unit FKIP Jambi University who has provided support in the form of funds so that this research can take place.

\section{References}

Anam, K. (2016). Pembelajaran Berbasis Inkuiri Metode dan aplikasi. Yogyakarta: Pustaka Pelajar.

Fathurrohman, M. (2015). Paradigma Pembelajaran Kurikulum 2013 Strategi Alternatif Pembelajaran di Era Global. Yogyakarta: Kalimedia.

Greenstein, L. (2012). Assessing 21st Century Skill: A Guide to Evaluating Mastery and Authentic Learning. United States of America: Corwin A Sage Company.

Huda, M. (2014). Model-model Pengajaran dan Pembelajaran. Yogyakarta: Pustaka Pelajar.

Prasetyo, B., \& Trisyanti, U. (2018). Revolusi industri 4.0 dan tantangan perubahan sosial. IPTEK Journal of Proceedings Series, (5), 22-27.

Sumartini, T.S. (2019). Kemampuan Komunikasi Matematis Mahasiswa Melalui Pembelajaran Think Talk Write. Mosharafa: Jurnal Pendidikan Matematika. Volume 8 Nomor 3 September 2019 hal. 377-388.

Suwardana, H. (2018). Revolusi Industri 4. 0 Berbasis Revolusi Mental. JATI UNIK: Jurnal Ilmiah Teknik Dan Manajemen Industri, 1(2), 109-118.

Tim Pengajar Deakin. (2013). The Series of Teaching Resources. Melbourne: DLF.

Tjandrawinata, R.R. (2016). Industri 4.0 : Revolusi Industri Abad Ini dan Pengaruhnya pada Bidang Kesehatan dan Bioteknologi. MEDICINUS. Vol. 29(1) : 31-39.

Trianto. (2008). Mendesain Pembelajaran Kontekstual di Kelas. Jakarta: Cerdas Jakarta Publisher.

Putra, S. R. (2013). Desain Belajar Mengajar Kreatif Berbasis Sains. Yogyakarta: Diva Press. 